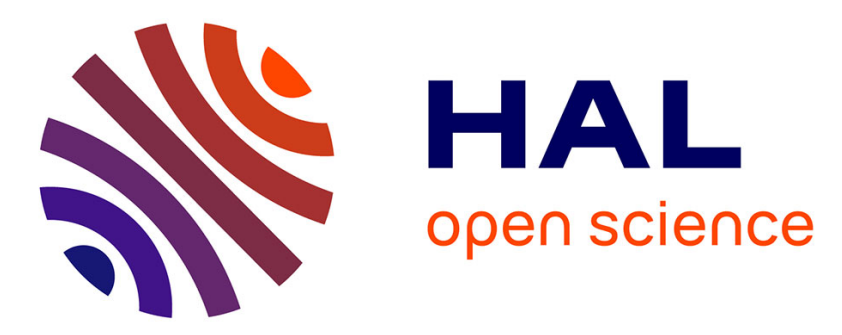

\title{
Measurement of plant xylem water pressure using the high-capacity tensiometer and implications for the modelling of soil-atmosphere interaction
}

Roberta Dainese, Alessandro Tarantino

\section{- To cite this version:}

Roberta Dainese, Alessandro Tarantino. Measurement of plant xylem water pressure using the highcapacity tensiometer and implications for the modelling of soil-atmosphere interaction. Geotechnique, 2021, 71 (5), pp.441-454. 10.1680/jgeot.19.P.153 . hal-03222923

\section{HAL Id: hal-03222923 \\ https://hal.inrae.fr/hal-03222923}

Submitted on 11 May 2021

HAL is a multi-disciplinary open access archive for the deposit and dissemination of scientific research documents, whether they are published or not. The documents may come from teaching and research institutions in France or abroad, or from public or private research centers.
L'archive ouverte pluridisciplinaire HAL, est destinée au dépôt et à la diffusion de documents scientifiques de niveau recherche, publiés ou non, émanant des établissements d'enseignement et de recherche français ou étrangers, des laboratoires publics ou privés.

\section{(c)(1)}

Distributed under a Creative Commons Attribution| 4.0 International License 


\title{
Measurement of plant xylem water pressure using the high-capacity tensiometer and implications for the modelling of soil-atmosphere interaction
}

\author{
ROBERTA DAINESE* and ALESSANDRO TARANTINO†
}

\begin{abstract}
The response of shallow geotechnical structures is affected by interaction with the atmosphere. Since the ground surface is very often vegetated, plant transpiration plays a major role in such an interaction. Transpiration in geotechnical applications is generally modelled by way of a transpiration reduction function (e.g. the Feddes function). However, its parameters are generally borrowed from the agricultural literature, where the focus is on crop species and often loosely compacted organic agricultural soils. For the non-crop species in denser soils typically encountered in geotechnical applications, monitoring of the flow taking place in the soil through the xylem up to the leaves can potentially be exploited to characterise the transpiration reduction function. The main challenge is the measurement of the water pressure in the xylem. Techniques currently used include the pressure chamber and thermocouple psychrometer. The pressure chamber is destructive and thus not suitable for continuous monitoring and/or where a relatively small number of leaves is available (as often occurs in laboratory experiments). The thermocouple psychrometer is not accurate at low water tension, is affected by the presence of solutes in the xylem water and is significantly sensitive to temperature. This paper explores a novel application of the high-capacity tensiometer (HCT), initially developed for porewater pressure measurement in soils. The HCT was installed on the stem or branch of different trees and its measurement validated against pressure chamber measurements over a range of xylem water pressure down to $-1300 \mathrm{kPa}$. In addition, its measurement was used to investigate the response of the soil-plant continuum. Results show that the HCT is a viable and convenient instrument to use for xylem water pressure measurement and can provide field-based data for the modelling of plant transpiration. Installing HCTs on stems and branches is quite straightforward and this will help achieve a step change in testing and modelling the effect of plant transpiration on the soil water regime in the vadose zone.
\end{abstract}

KEYWORDS: environmental engineering; field instrumentation; suction; vegetation

\section{INTRODUCTION}

The response of the shallow portion of the ground (vadose zone) and earth structures is affected by interaction with the atmosphere. Rainwater infiltration and evapotranspiration cause settlement and heave in shallow foundations and embankments, and control the stability of man-made and natural slopes.

The ground surface is often covered by vegetation and, as a result, transpiration plays a major role in the mechanisms of water removal by the atmosphere. Transpiration is the process of water movement taking place from the soil through the plant up to the leaves, where water eventually evaporates through the stomata.

A very common approach to model water uptake by vegetation macroscopically is to consider actual transpiration $T$ as the product of the potential (energy-limited) transpiration $T_{\mathrm{P}}$ times a reduction factor $\alpha$, assumed to be a function

Manuscript received 31 May 2019; revised manuscript accepted 10 February 2020. Published online ahead of print 21 April 2020. Discussion on this paper closes on 1 September 2021, for further details see p. ii.

* Department of Civil and Environmental Engineering, University of Strathclyde, Glasgow, UK; also CIRAD - UMR AMAP and Université de Montpellier, Montpellier, France

(Orcid:0000-0001-8304-3396).

$\dagger$ Department of Civil and Environmental Engineering, University of Strathclyde, Glasgow, UK. of the pore-water pressure, $u_{\mathrm{w}}$, in the root zone

$$
T=T_{\mathrm{P}} \alpha\left(u_{\mathrm{w}}\right)
$$

Under optimal soil water conditions, the root water extraction rate is equal to the maximum transpiration rate, $T_{\mathrm{P}}$ $(\alpha=1)$. Under non-optimal conditions - that is when the soil is either too dry or too wet - transpiration is reduced by means of the factor $\alpha(\alpha<1)$.

Feddes et al. (1978) assumed that the reduction factor is a function of soil pore-water pressure as presented in Fig. 1. The transpiration is assumed to be equal to zero for a $u_{\mathrm{w}}$ higher than $u_{\mathrm{w} 1}$, the 'anaerobiosis point', and below the wilting point $u_{\mathrm{w} 4}$; the transpiration is maximum $(\alpha=1)$ between $u_{\mathrm{w} 2}$ and $u_{\mathrm{w} 3}$, with the latter corresponding to the pore-water pressure in the soil below which plant growth starts to be limited. The pore-water pressure $u_{\mathrm{w} 3}$ marks the transition from the energy-limited (potential) transpiration to the water-limited transpiration and is the most critical parameter of the Feddes function (Nyambayo \& Potts, 2010).

The approach proposed by Feddes et al. (1978) to model the reduction factor is widely used in geotechnical applications (Hemmati et al., 2010; Nyambayo \& Potts, 2010; Greco et al., 2013; Briggs et al., 2016; Tsiampousi et al., 2017; Pagano et al., 2019; Zhu \& Zhang, 2019). This approach is convenient because it only requires information about the pore-water pressure in the root zone without the need to address the complex interaction between the soil, the plant, and the atmosphere. 


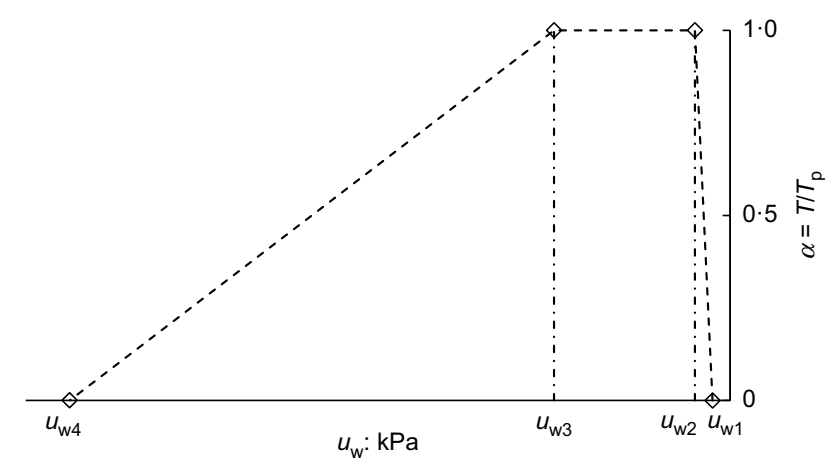

Fig. 1. Feddes reduction function (Feddes, 1982)

However, this simplicity is only apparent because the complexity of such an interaction is hidden in the choice of the Feddes parameters. In reality, it is actually the water pressure in the leaf and not the pore-water pressure $u_{\mathrm{w} 3}$ in the soil that dictates the transition from the energy-limited to the water-limited regime, thanks to mechanisms of stomata closure triggered when the water pressure in the leaf falls below certain thresholds (Gollan et al., 1985).

The problem of the choice of the Feddes parameters is reflected in the very wide range of parameters adopted in the literature for $u_{\mathrm{w} 3}$ as reported in Table 1. Feddes et al. (1978) proposed $u_{\mathrm{w} 3}=-40 \mathrm{kPa}$, but a wide range of values for $u_{\mathrm{w} 3}$ have been derived by Wesseling (1991) and Utset et al. (2000) depending on the nature of the crop and the level of potential transpiration rate. When the Feddes function is used in geotechnical applications, the parameter $u_{\mathrm{w} 3}$ is generally borrowed from the agricultural literature. This approach may be questionable as the parameters derived for crop species and often loosely compacted organic agricultural soils may differ significantly from non-crop species in the often densely compacted soils that are typically encountered in geotechnical applications (Garg et al., 2015).

To cope with this uncertainty, Nyambayo \& Potts (2010) have analysed the sensitivity of the transpiration model to the parameter $u_{\mathrm{w} 3}$ and concluded that this parameter had little effect on the simulated pore-water pressure distribution. However, as acknowledged by the same authors, this finding may be specific to the climate and soil conditions they have investigated and should not be generalised. Garg et al. (2015) designed a laboratory programme on Schefflera heptaphylla vegetated in compacted silty sand to derive experimentally the Feddes parameters for non-crop species. However, their method is applicable to laboratory conditions and would be difficult to implement in the field.

The reduction function under field conditions can be investigated by monitoring the soil-plant-atmosphere continuum (SPAC) as illustrated later in the paper and this includes the measurement of the (negative) xylem water pressure in the plant. The most common techniques to measure xylem water potential are the pressure chamber (Scholander et al., 1965) and the thermocouple psychrometer (Martinez et al., 2011). The working principle of the pressure chamber is the same as the axis-translation technique used to measure matric suction in soils (Marinho et al., 2008). Air pressure is increased around the xylem/leaf until water pressure is 'translated' from negative values to zero. This is a destructive technique and it is not suitable for continuous measurement and/or for monitoring leaf water pressure when a relatively small number of leaves is available. Furthermore, the design of the pressure chamber makes the measurement very difficult in locations other than leaves and small twigs.

The thermocouple psychrometer is similar in concept to the instruments used to measure total suction in soils by way of the vapour-phase equilibrium (Bulut \& Leong, 2008). It is widely used in the field for continuous monitoring of xylem/ leaf water potential, but its measurement is affected by the presence of solutes in the xylem water (osmotic suction). The common assumption that solutes have negligible effects (Jones, 2006) does not always hold (Campbell \& Gardner, 1971; Goode \& Higgs, 1973) and this can make the thermocouple psychrometer measurement difficult to interpret. Another limitation of the thermocouple psychrometer is the poor accuracy at values of (negative) xylem water pressure close to zero (high relative humidity) and the sensitivity to temperature, which is a critical issue in field measurements (Martinez et al., 2011).

A direct measurement of xylem water pressure was attempted by Balling \& Zimmermann (1990), using a pressure probe made of a capillary tube filled with water and silicone oil. However, the probe failed to register vessel water pressures below $-0.65 \mathrm{MPa}$ (Wei et al., 2001) and measurements lasted no more than a few hours due to cavitation occurring in the probe (Balling \& Zimmermann, 1990). This was probably due to the absence of a high-air-entry porous

Table 1. Values of the Feddes function, suggested by Feddes et al. (1978) and adopted in agricultural and geotechnical applications

\begin{tabular}{|c|c|c|c|c|}
\hline & $u_{\mathrm{w} 1}: \mathrm{kPa}$ & $u_{\mathrm{w} 2}: \mathrm{kPa}$ & $u_{\mathrm{w} 3}: \mathrm{kPa}$ & $u_{\mathrm{w} 4}: \mathrm{kPa}$ \\
\hline \multicolumn{5}{|l|}{ Feddes model } \\
\hline Feddes et al. (1978) & -5 & -5 & -40 & -1500 \\
\hline \multicolumn{5}{|l|}{ Agricultural crop models } \\
\hline \multicolumn{5}{|l|}{ Wesseling (1991) } \\
\hline Potatoes & -1 & $-2 \cdot 5$ & $-32 /-60$ & -1600 \\
\hline Sugar beet & -1 & $-2 \cdot 5$ & $-32 /-60$ & -1600 \\
\hline Wheat & 0 & $-0 \cdot 1$ & $-50 /-90$ & -1600 \\
\hline Pasture & -1 & $-2 \cdot 5$ & $-20 /-80$ & -800 \\
\hline Corn & $-1 \cdot 5$ & -3 & $-32 \cdot 5 /-60$ & -800 \\
\hline \multicolumn{5}{|l|}{ Utset et al. (2000) } \\
\hline Potatoes & -1 & $-3 \cdot 5$ & $-32 /-60$ & -800 \\
\hline \multicolumn{5}{|l|}{ Geotechnical models } \\
\hline Indraratna et al. (2006) & -5 & -5 & -40 & -1500 \\
\hline Nyambayo \& Potts (2010) & 0 & -5 & $-100 /-400$ & -1500 \\
\hline Hemmati et al. (2010) & $-4 \cdot 9$ & $-4 \cdot 9$ & -40 & -1500 \\
\hline Greco et al. (2013) & 0 & -5 & -150 & -1500 \\
\hline Briggs et al. (2016) & 0 & 0 & -100 & -1500 \\
\hline Tsiampousi et al. (2017) & 0 & -5 & -50 & -1500 \\
\hline Garg et al. (2015); Zhu \& Zhang (2019) & $-0 \cdot 1$ & -5 & $-52 /-90$ & -1500 \\
\hline
\end{tabular}


interface, which is actually incorporated into the highcapacity tensiometer (HCT) used to measure $u_{\mathrm{w}}$ in soil (Marinho et al., 2008).

This paper presents a novel use of a HCT to monitor the negative xylem water pressure in plants. The measurement of the HCT was validated against the pressure chamber over a relatively wide range of xylem water pressures by way of field and laboratory experiments.

The HCT was then exploited to characterise the interaction between soil and plant by monitoring simultaneously the water pressure in the xylem and soil under energy-limited (potential) and water-limited transpiration regimes. The aim was to demonstrate that the joint measurement can allow the transpiration reduction function specific to a given soil and plant to be characterised.

\section{BACKGROUND}

The flow of water within the plant is driven by the water pressure differential between the soil and the leaves (Pickard, 1981). Water flows radially from the soil across the layers of root living cells, into the xylem at the centre of the root (Fig. 2(a)). It then flows upwards in the stem through the xylem (Fig. 2(b)), which is part of the apoplast, the 'dead' part of the plant. The xylem is characterised by a porous structure made of vessels (diameter $\varnothing \sim 300 \mu \mathrm{m}$ ) and tracheids (diameter $\varnothing \sim 40 \mu \mathrm{m}$ ). These are similar to capillary tubes (Canny, 1977) and act as conduits for the transport of water. The water flows mainly vertically through the xylem, driven by the negative water pressure at the leaves. Under normal conditions, the water in the xylem is continuous and under tension and this allows the ascent of water to considerable heights. If the xylem water tension becomes too high, embolism (cavitation) may occur in some of the transporting channels, preventing the flow of water from occurring any further in the channel itself. When water reaches the leaves, it tends to evaporate from the wet surface of the mesophyll cells (Fig. 2(c)). The carbon dioxide $\left(\mathrm{CO}_{2}\right)$ and water exchange in the leaves, related to the processes of photosynthesis and transpiration, is regulated by the guard cells, controlling the closing and opening of stomata.

\section{EQUIPMENT}

High-capacity tensiometer

The HCT used in this experimental work is based on the design of Tarantino \& Mongiovì (2002). The HCT is shown in Fig. 3 and is composed of an integral strain gauge, a diaphragm $0.4 \mathrm{~mm}$ thick and a ceramic filter with nominal air-entry value of $1.5 \mathrm{MPa}$. When the instrument is placed in contact with the xylem, the tension of the xylem water is transferred to the water reservoir, deflecting the diaphragm and deforming the strain gauge. The HCT measures the 'matric' water pressure in the sample, thanks to the free diffusion of ions through the porous ceramic (Tarantino, 2002).

\section{Pressure chamber}

The pressure chamber used in this experimental programme is commercialised by PMS Instrument Company (model 1515D). The working principle of the pressure chamber is similar to the axis-translation technique used to

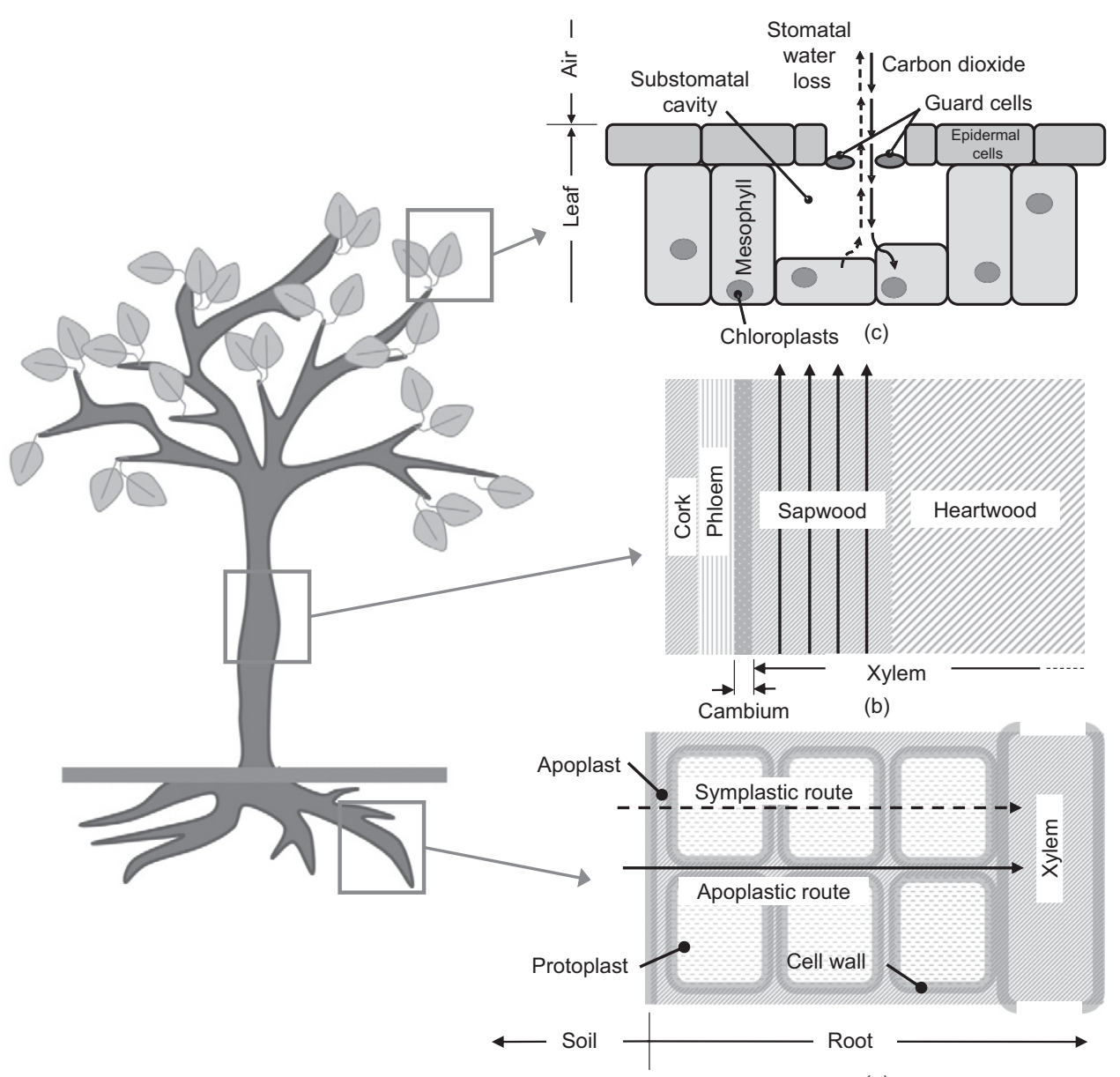

(a)

Fig. 2. (a) Radial flow from the soil to the root. (b) Structure of the stem and flow through the xylem. (c) Leaf structure: stomata and gas exchange 


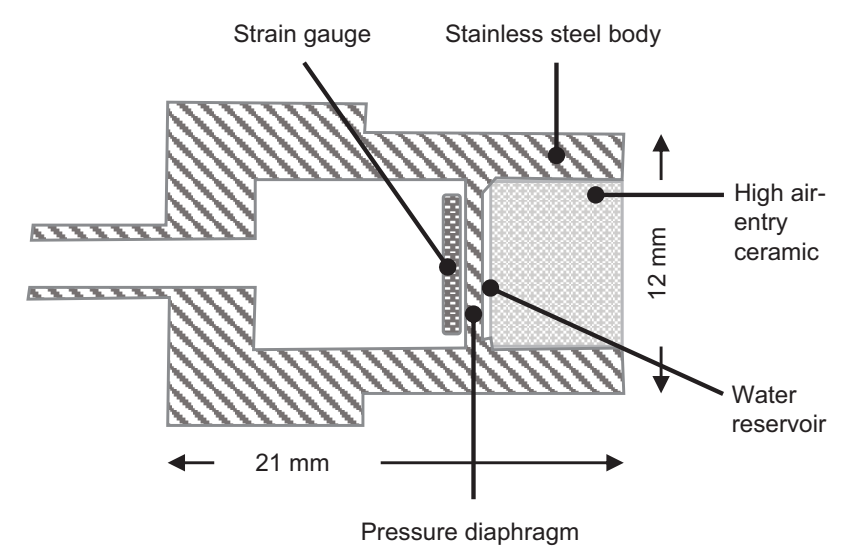

Fig. 3. High-capacity tensiometer (after Tarantino \& Mongiovì, 2002)

measure matric suction in soils (Marinho et al., 2008). In the plant, water in the leaf is under tension, whereas the air surrounding the leaf is at atmospheric pressure (Fig. 4(a)). When the leaf is excised, the water retracts into the petiole and menisci form at the interface between the cut end of the petiole and the atmosphere (Fig. 4(b)). In the pressure chamber, only the last part of the petiole is left outside in direct contact with the atmosphere (Fig. 4(c)). The air pressure in the chamber is then gradually incremented until water can be observed to form a flat meniscus on the excised end of the petiole (Fig. 4(c)). The air pressure is then taken as numerically equal to the water tension in the leaf before excision (Boyer, 1967). This technique is based on the assumption that the difference between the leaf water pressure and the surrounding air pressure remains constant throughout the whole procedure (Figs 4(d) and 4(e)) (Scholander et al., 1965).

The (negative) water pressure of the leaf measured by the pressure chamber may be used to assess the xylem water pressure on the stem at the base of the petiole, provided leaf

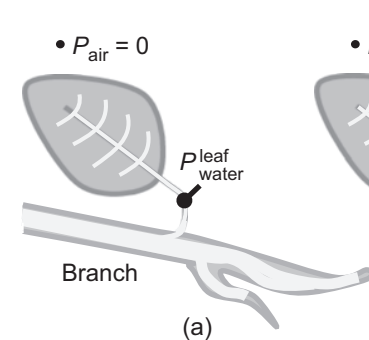

(a)

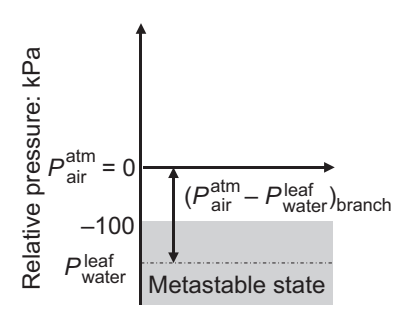

(d)

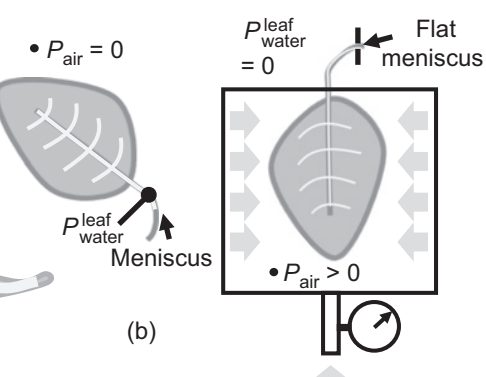

(c)

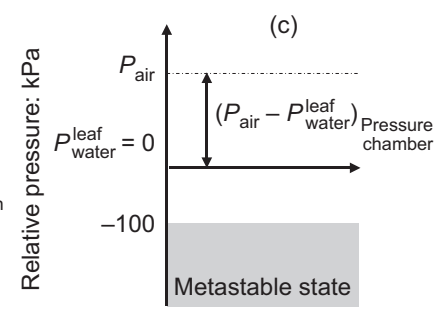

(e)

Fig. 4. Working principle of the pressure chamber technique for measurement of leaf water pressure: (a) leaf on the tree (water pressure is negative); (b) leaf excised (curved meniscus forming at the end of petiole); (c) air pressure increased around leaf (meniscus becomes flat). (d) Air and leaf water pressure on the branch. (e) Air and leaf water pressure in the pressure chamber at equilibrium when the reading is taken transpiration is prevented and water in the leaf is allowed to reach equilibrium with the xylem at the junction with the stem (Lang \& Barrs, 1965; Richter, 1973).

The pressure chamber is a commonly used and trusted technique in plant science to measure the leaf and xylem water pressure and has often been used as a benchmark to validate several other measurement techniques (Scholander et al., 1965; Brown \& Tanner, 1981; Turner et al., 1984; Balling \& Zimmermann, 1990; Boyer, 1995).

The absence of an independent reference measurement of the xylem water pressure makes it difficult to quantify the accuracy of the pressure chamber. It is only possible to assess the precision of the measurement when multiple leaves in comparable conditions are tested.

\section{MATERIALS}

The results presented in this paper include one test in the field on a chestnut tree and two tests in the laboratory, on a pear tree and on a willow tree, respectively. The three selected plants are angiosperms, whose xylem is characterised by broad $(150 \mu \mathrm{m})$ continuous vessels in a matrix of fibres. Vessel connectivity reduces potential local variability of the xylem water potential.

The chestnut (Castanea sativa Mill.) belongs to the family of Fagaceae and is part of a chestnut plantation located in Penisola Sorrentina, Naples, Italy, at about $850 \mathrm{~m}$ above sea level. The age of the plant is approximately 15 years, the diameter of the trunk at breast height and the total height of the plant are around $20 \mathrm{~cm}$ and $8-10 \mathrm{~m}$, respectively. The soil is a pyroclastic soil, presenting a shallow layer of organic matter, a layer of cinerite and angular pumices with a thickness varying from a few millimetres to a few centimetres, and an underlying layer of 3-4 cm angular pumices at least $1 \mathrm{~m}$ thick (Rodrigues Afonso Dias, 2019).

The two plants tested in the laboratory were taken from a nursery. The pear tree (Pyrus communis) was tested in its original pot, which contained highly organic and loose soil (92\% organic matter, $8 \%$ sandy silt (68\% silt, $32 \%$ sand)). At the time of the experiment, the plant was approximately $2.30 \mathrm{~m}$ high and the diameter of the stem at $100 \mathrm{~mm}$ from the soil was around $17 \mathrm{~mm}$. The shrub willow (Salix cinerea) was transplanted into a pot of silty sand (73\% sand, $23 \%$ silt, $4 \%$ clay) with the hydraulic properties shown in Fig. 5. The water retention curve was determined along a main drying path from local measurements of volumetric water content and pore-water pressure along the pot height; the unsaturated hydraulic conductivity is described through the Brooks and Corey equation (Brooks \& Corey, 1964) with the parameters

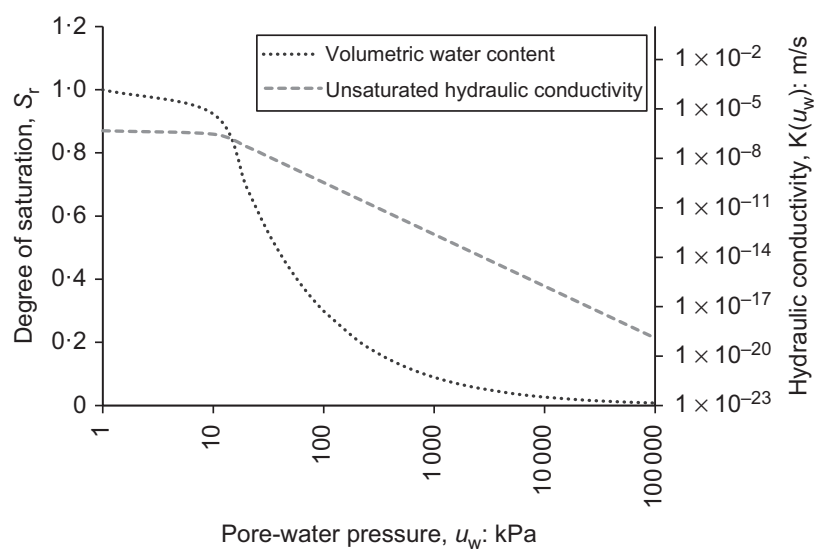

Fig. 5. Water retention and hydraulic conductivity characteristics of the soil in the willow tree test 
derived by inverse analysis of the water flow in the soil generated by evaporation (to match the time variation of volumetric water content and pore-water pressure).

In the new container, the willow grew two main branches, reaching a height of about $150 \mathrm{~cm}$. The diameter of the stem at $100 \mathrm{~mm}$ from the soil was around $16 \mathrm{~mm}$.

\section{EXPERIMENTAL PROCEDURES}

Tests aimed at comparing xylem water pressure measured by the HCTs and the pressure chamber were carried out on a chestnut tree in the field and on the pear and willow trees in the laboratory. The aim of the test was to investigate the interaction between soil and plant by joint measurement of water pressure in the soil and xylem only involving the willow tree.

\section{Xylem water pressure measurement}

High-capacity tensiometer. Adequate saturation of HCTs was achieved by cycles of cavitation followed by prolonged periods of pressurisation at $4 \mathrm{MPa}$ (Tarantino, 2002). Before each measurement, the probe was zeroed, following the procedure described by Tarantino \& Mongiovì (2003). At the end of each test, the post-measurement checks were different depending on whether the HCT cavitated during the measurement. If cavitation did not occur, the HCT was placed in free water to verify that zero pressure was recovered (a residual water pressure of $10-20 \mathrm{kPa}$ was considered acceptable according to Tarantino \& Mongiovì (2001)). If cavitation occured during the measurement, it was checked to ensure that the gauge pressure jumped to $-100 \mathrm{kPa}$ upon cavitation.

The HCTs could be installed on trunks or branches provided their diameter was greater than about $15 \mathrm{~mm}$. The bark and the living tissues of the plant (phloem and cambium) were removed to expose the xylem underneath (Fig. 6(a)). The xylem surface was then cleaned with some drops of distilled water. The xylem surface was usually kept moist during the installation to avoid excessive dehydration of the tissues. HCTs were applied to the stem using a thin film of kaolin clay paste at approximately the liquid limit interposed between the porous ceramic filter and the xylem (Fig. 6(b)). A latex membrane was then used to cover the paste to avoid evaporation from the paste (Fig. 6(c)). The paste ensured hydraulic continuity between the porous ceramic filter and the plant xylem. The water content of the paste was a compromise between two competing requirements: water content should be as high as possible for the paste to adhere to the irregular xylem surface and as low as possible to minimise the time required for hydraulic equilibration between the xylem and paste.

Pressure chamber. Leaves were initially wrapped in aluminium foil for at least $10 \mathrm{~min}$, as suggested by the

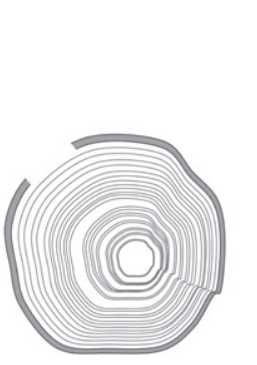

(a)

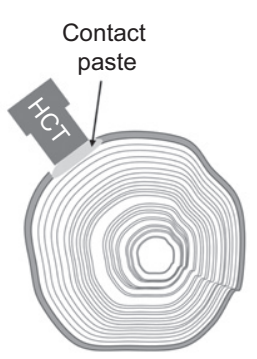

(b)

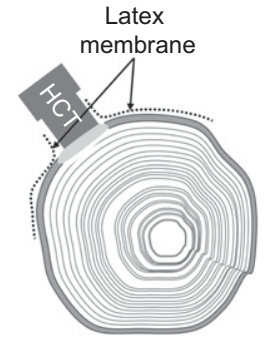

(c)
Fig. 6. HCT installation on stem: (a) exposure of xylem tissues; (b) HCT application; (c) sealing with latex membrane manufacturer (PMS Instrument Company, 2019). Leaf wrapping stops transpiration and allows water in the leaf to equilibrate with the branch. As a result, the water pressure recorded in the leaf is assumed to coincide with the water pressure in the branch at the base of the petiole (Richter, 1973).

The leaf was then excised with a sharp blade and promptly inserted into the pressure chamber, apart from the end of the excised petiole, which was kept outside the chamber at atmospheric pressure. The air in the chamber was gradually pressurised until a flat meniscus formed at the end of the excised petiole (Meron et al., 1987). The air pressure in the chamber recorded when the flat meniscus appeared was assumed to be equal to the negative water pressure in the leaf before excision.

\section{Field test on chestnut}

The experiment was carried out on a chestnut grove in Monte Faito, Naples, Italy. Two HCTs were applied $10 \mathrm{~cm}$ apart on the branch of a chestnut at around $1.5 \mathrm{~m}$ from the soil (Fig. 7). The HCTs were kept in place for approximately $80 \mathrm{~h}$ uninterruptedly to monitor the evolution of xylem water pressure at different times of the day. Measurements were recorded along four time intervals as shown in the timeline in Fig. 9 (the data acquisition system was connected to the HCTs only at these times). Measurements of xylem water pressure by the pressure chamber were taken on sets of six leaves, sampled from the same branch where the HCTs were installed. The leaf wrapping time was set to $10 \mathrm{~min}$. Leaves taken before dawn, in darkness, were not covered before excision as the stomata were assumed to be close overnight, with the leaf not transpiring (Deloire \& Heyns, 2011).

\section{Laboratory experiments on pear tree and willow tree}

Experiments were carried out in a temperature-controlled room, with a growth lamp to mimic solar radiation. Transpiration was accelerated by exposing the trees to ventilation generated by a fan (Table 2). Each test started with the soil in fully saturated conditions. A condition of drought was then allowed to develop by avoiding any watering of the soil for the whole duration of the test.

Pear tree. Two HCTs were installed on the stem of a pear tree, in the position reported in Fig. 8(a) and Table 3. The

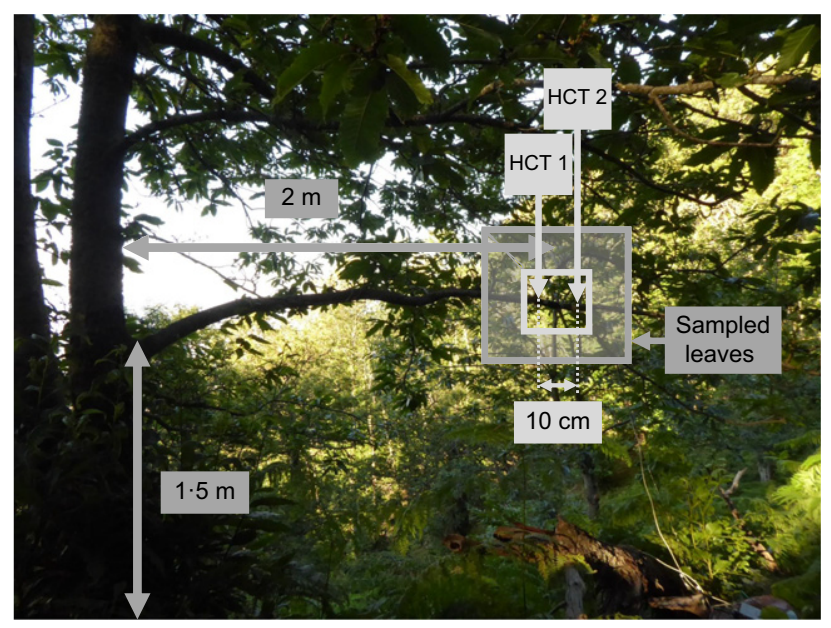

Fig. 7. Location of the HCTs installed on chestnut tree measuring site and of the area where the set of leaves was sampled for pressure chamber measurements 


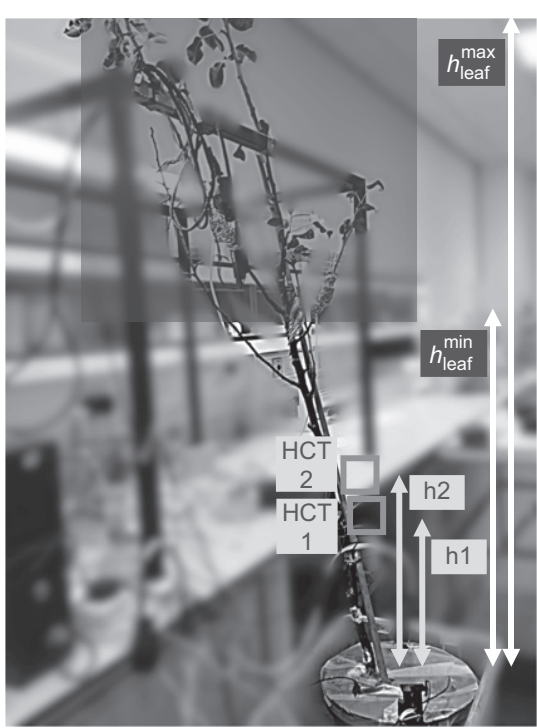

(a)

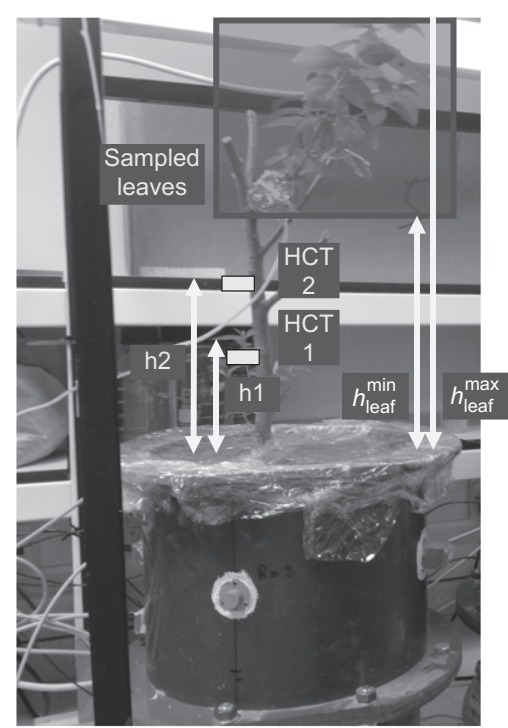

(b)

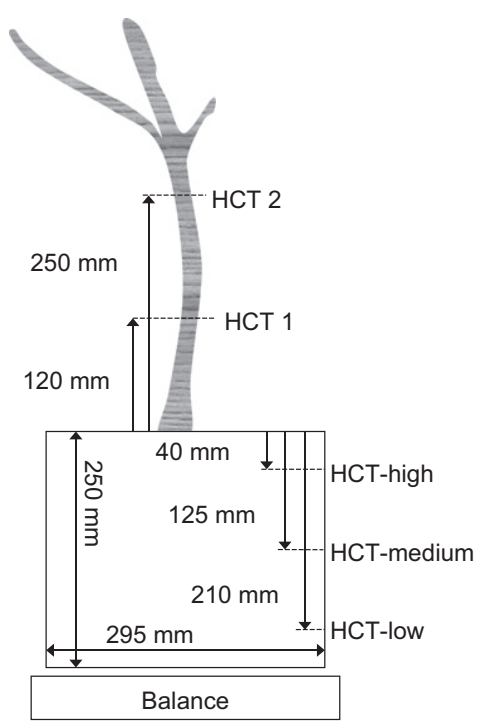

(c)

Fig. 8. (a) Pear tree set-up and (b) willow tree set-up for comparison of xylem water measurement; (c) willow tree set-up for the investigation of the soil-plant interaction

Table 2. 'Atmospheric' boundary conditions imposed in the laboratory test

\begin{tabular}{l|l}
\hline Stage & BC2 \\
\hline First test: pear tree & \\
$\quad$ Time interval: days & $0-7$ \\
$\quad$ Forced ventilation (fan) & Yes \\
Second test: willow tree & $0-89$ \\
$\quad$ Time interval: days & Yes \\
$\quad$ Forced ventilation (fan) & \\
Daily cycle: & 14 \\
$\quad$ Growth lamp: h & 10 \\
$\quad$ Darkness: $\mathrm{h}$ & \\
Environmental conditions: & 20 \\
$\quad$ Temperature: ${ }^{\circ} \mathrm{C}$ & $\sim 45$ \\
$\quad$ Relative humidity: $\%$ & \\
\hline
\end{tabular}

Table 3. Location of HCTs and leaves sampled for pressure chamber measurements in laboratory experiments

\begin{tabular}{l|l|r|r}
\hline \multirow{2}{*}{ Measurement } & \multicolumn{3}{|c}{ Distance: cm } \\
\cline { 2 - 4 } & \multicolumn{2}{|c}{ Pear tree } & Willow tree \\
\hline \multirow{2}{*}{ HCT } & $h_{1}$ & 40 & 12 \\
\multirow{2}{*}{ Leaves } & $h_{2}$ & 50 & 25 \\
& $h_{\text {leaf }}^{\min }$ & 120 & 35 \\
& $h_{\text {leaf }}^{\text {max }}$ & 190 & 150 \\
\hline
\end{tabular}

experiment lasted for 8 days, with continuous monitoring of xylem water pressure by HCTs and discontinuous periodic monitoring of leaf water pressure using the pressure chamber.

The leaves used for pressure chamber measurements were excised from branches above the HCTs. Measurement of leaf water pressure was carried out using two different procedures. The first procedure was the 'standard' 10 min wrapping in aluminium foil (PC $10 \mathrm{~min}$ ). The second procedure was associated with a different test run in parallel on the same set-up, which is not discussed in this paper. Leaves were wrapped in aluminium foil and Parafilm for several days, unwrapped, exposed to air for a few minutes, and then excised for the measurement with the pressure chamber (PC_>1 day).

Willow tree. The willow was initially transplanted into a column holding a silty sand sample with $295 \mathrm{~mm}$ dia. and $230 \mathrm{~mm}$ high, and allowed to grow into it for 2 months. Two HCTs were installed on the stem and periodical readings of leaf water pressure were taken using the pressure chamber (the position of the instruments is shown in Figs 8(b) and 8(c) and Table 3 ). Readings by pressure chamber were based on sets of three leaves with a wrapping time of at least $2 \mathrm{~h}$, according to Patakas et al. (2005), who suggested a wrapping time greater than $1 \mathrm{~h}$ for plants under stress (i.e. subjected to very low xylem water pressure).

Additional HCTs were applied to the sides of the column at different depths to monitor the evolution of the negative pore-water pressure in the soil. The conditioning of the HCTs applied to the soil was analogous to the procedure used for the HCTs on the stem. The contact paste was made from the fine part of the silty sand used for the specimen $(<53 \mu \mathrm{m})$ (Marinho et al., 2008).

The column was placed on a balance to monitor the water loss over time and, hence, the transpiration rate. The soil surface was covered with a plastic film to prevent evaporation from the bare soil and allow the sole transpiration to take place from the leaves.

\section{EXPERIMENTAL RESULTS \\ Comparison between HCT and pressure chamber measurements of xylem water pressure}

Field test on chestnut. Figure 9 shows the measurement of two HCTs together with the pressure chamber measurement (the average of each set of leaves is indicated by a cross). Fig. 9(a) shows the initial installation of the HCTs. The initial decrease in pressure from 1.00 p.m. (shown as 13:00 in Fig. 9) to 4.30 p.m. (16:30) is associated with the hydraulic equilibration between the branch xylem and the saturated paste, which loses water in favour of the xylem until the elements in contact are at the same water pressure. The increase in pressure recorded by the HCTs after 4.30 p.m. (16:30) is an indicator of the hydraulic equilibrium achieved 

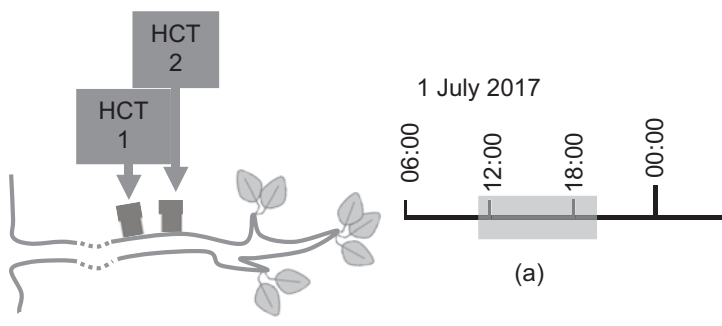

(a)

2 July 2017

3 July 2017

4 July 2017

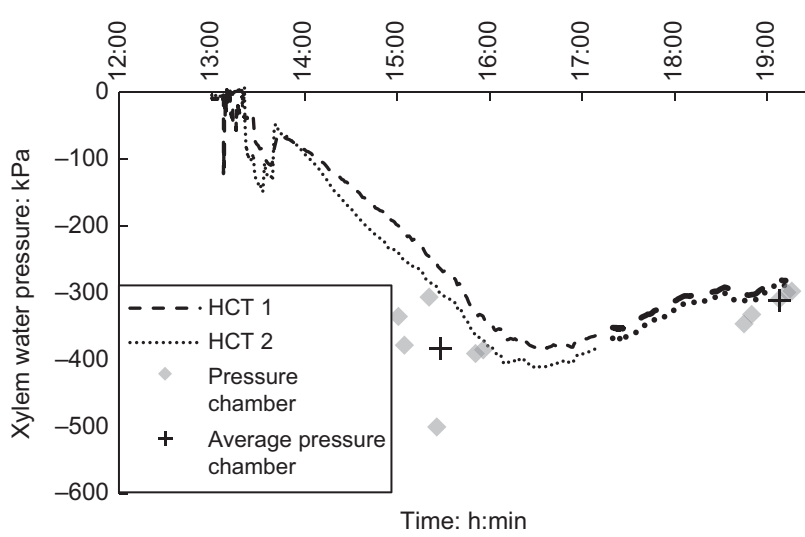

(a)

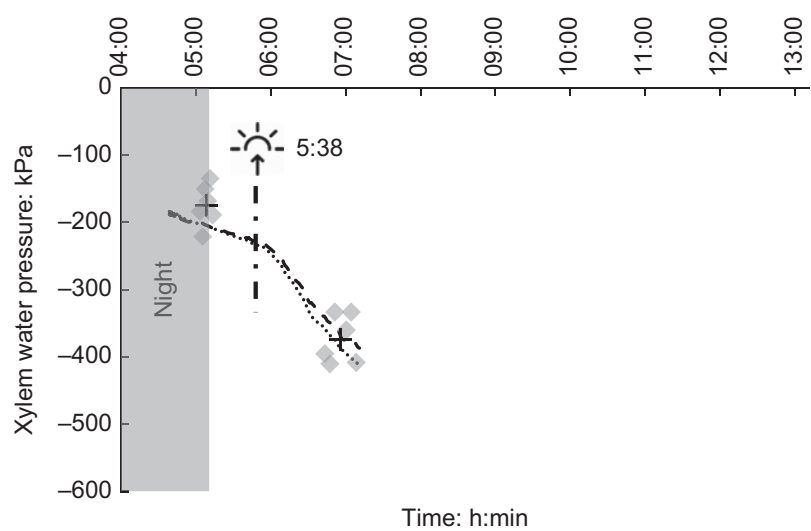

(c)

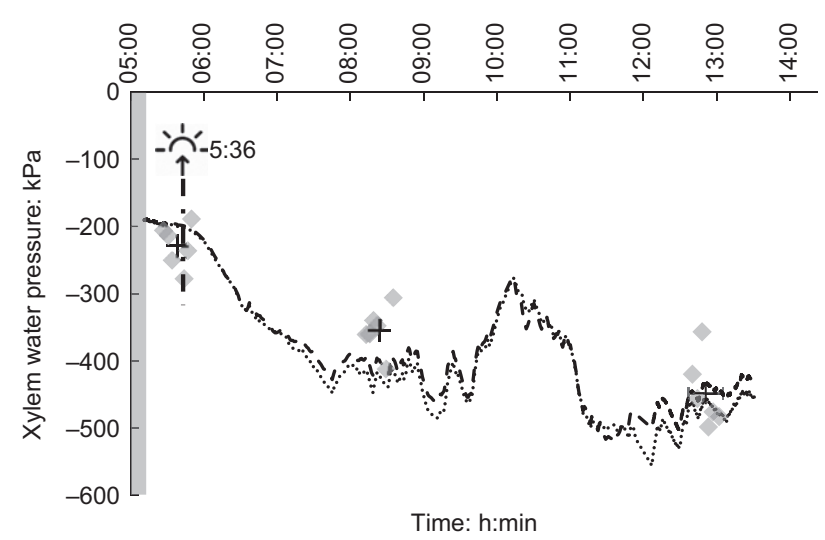

(b)

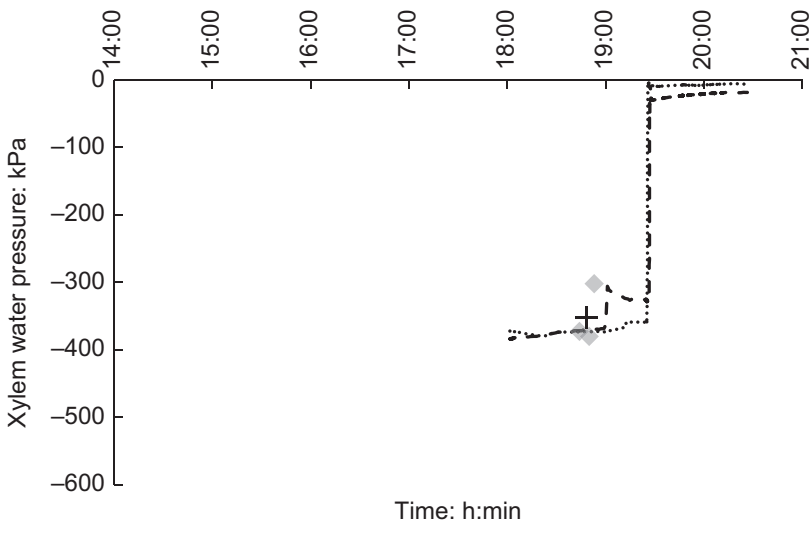

(d)

Fig. 9. Measurements of xylem water pressure using HCT and leaf water pressure using pressure chamber on chestnut tree: (a) 1 July 2017; (b) 2 July 2017; (c) 3 July 2017; (d) 4 July 2017. Pressure chamber measurements are reported individually and average pressure chamber measurement is indicated by a cross

between the water pressure in the xylem and in the paste and, hence, the HCT. The increase in xylem water pressure after 4.30 p.m. (16:30) is associated with the decrease of solar radiation occurring at the end of the afternoon. It is worth noticing that the first measurement with the pressure chamber (Fig. 9(a)) was taken when the hydraulic equilibrium between the branch and the instrument had not yet been achieved.

Figure 9(b) shows the measurement at dawn, with an almost stable reading of approximately $-200 \mathrm{kPa}$ between $5.15 \mathrm{a} . \mathrm{m}$. $(05: 15)$ (start of the measurement) and 5.36 a.m. (05:36) (sunrise). As soon as the sun rose, the xylem pressure started to decrease at a faster rate because of the exposure of the leaves to sunlight and the consequent opening of the stomata. The xylem water pressure stabilised at around $-400 \mathrm{kPa}$ between 8.00 a.m. (08:00) and 1.30 p.m. (13:30). The slight increase in xylem pressure between 9.30 a.m. (09:30) and 11.00 a.m. (11:00) was associated with clouds that partially shadowed the canopy, showing a high sensitivity of the HCTs to xylem pressure adjustments. The pressure chamber measurements were taken at 5.40 a.m. (05:40), before sunrise, and at 8.35 a.m. (08:35) and 1.00 p.m. (13:00).

Figure 9(c) shows that the measurement starting at 4.30 a.m. (04:30) (night-time before dawn) is around $180 \mathrm{kPa}$. This is in line with values of leaf water pressure measured at pre-dawn by Kocher et al. (2009), which ranged from -100 to $-1250 \mathrm{kPa}$ depending on the broadleaf species considered. The pattern is similar to Fig. 9(b) with the xylem water pressure decreasing significantly after sunrise. Fig. 9(d) shows the last time interval, including the post-measurement check.

Overall, the two HCTs measured approximately the same xylem pressure. This was not surprising as the two HCTs were placed at a distance of only $10 \mathrm{~cm}$ on a branch segment with no twigs or secondary branches. The slight difference $(\sim 25 \mathrm{kPa})$ measured during daytime when transpiration was taking place is consistent with the direction of water flow that goes from the trunk towards the leaves (HCT 1 closer to the trunk recorded higher water pressures than HCT 2 closer to the leaves). During night-time, dawn and following a short 
period after sunrise, the two HCTs recorded very close values, which is again consistent with no or little transpiration taking place through the leaves over these periods.

Figure 10 shows the measurements from the pressure chamber plotted against the measurement of water pressure by the HCTs recorded at the time of pressure chamber measurement (the average of each set of leaves is indicated by a cross). The first measurement by the pressure chamber was excluded because it was taken when the HCTs were not yet in equilibrium with the xylem water pressure. The measurements fairly align along a 1:1 line. The discrepancy between the HCT and the average pressure chamber measurement for each set is characterised by a standard deviation of 0.03 $\mathrm{MPa}$.

As shown in Fig. 10, the comparison between HCT and pressure chamber was explored over a limited range of xylem water pressure - that is, down to $-500 \mathrm{kPa}$ only. The

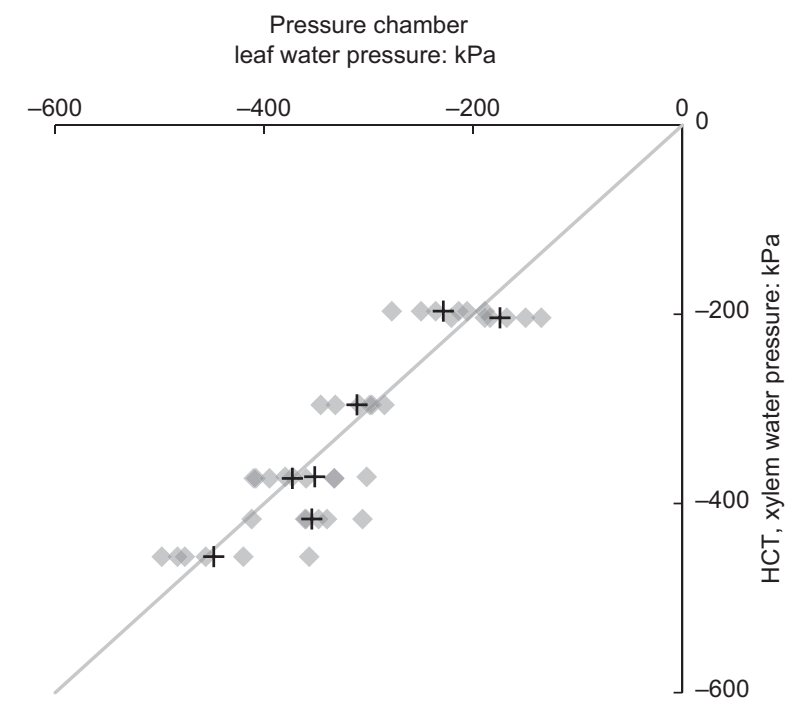

Fig. 10. Comparison of pressure chamber and HCT measurements on chestnut tree in the field. Pressure chamber measurements are reported against the average measurement of HCT and average pressure chamber measurement is indicated by a cross laboratory experiments illustrated below were then aimed at widening the range of measurements by purposely creating drought conditions.

Laboratory test on pear tree. Figure 11 shows the measurements of the HCTs installed on the stem and the measurement of leaf water pressure by the pressure chamber. The xylem water pressure ranged from $-300 \mathrm{kPa}$ to $-800 \mathrm{kPa}$.

The non-shadowed areas represent the daytime from 6 a.m. to 8 p.m. where solar radiation was mimicked using a growth lamp, whereas the shadowed areas in the graph represent the 'night time' from 8 p.m. to 6 a.m. when the growth lamp was switched off. The daily cycles of xylem water pressure are consistent with the day/night cycles imposed by the growth lamp and consistent with similar experiments reported in the literature (Jones, 2006). When the lamp was switched on at 6 a.m., leaf stomata opened and the daily transpiration commenced. Accordingly, the xylem water pressure recorded by the HCTs started to decrease. At the beginning of the afternoon, the water pressure started increasing and kept increasing during night-time.

The values recorded by the two HCTs were very similar during night-time, whereas a pressure differential was established during the daytime, consistent with experimental results from the literature (Begg \& Turner, 1970). The difference measured during daytime $(\sim 100 \mathrm{kPa})$ when transpiration was taking place is consistent with the direction of water flow.

The measurements of xylem water pressure using the pressure chamber on non-transpiring leaves were consistent regardless of the wrapping procedure used, $10 \mathrm{~min}$ or $>1$ day wrapping time. The measurement on the leaf, which is assumed to coincide with the xylem pressure in the branch at the base of the excised petiole, was lower than the xylem pressure recorded by the HCTs, which is consistent with the gradients associated with transpiration flow.

The relatively low repeatability of the pressure chamber measurement on 26 January is likely to be because leaves were sampled from two different branches. Pressure chamber measurements were similar for leaves excised from the same branch, but different from one branch to another. This may not be surprising if one considers the variability of xylem

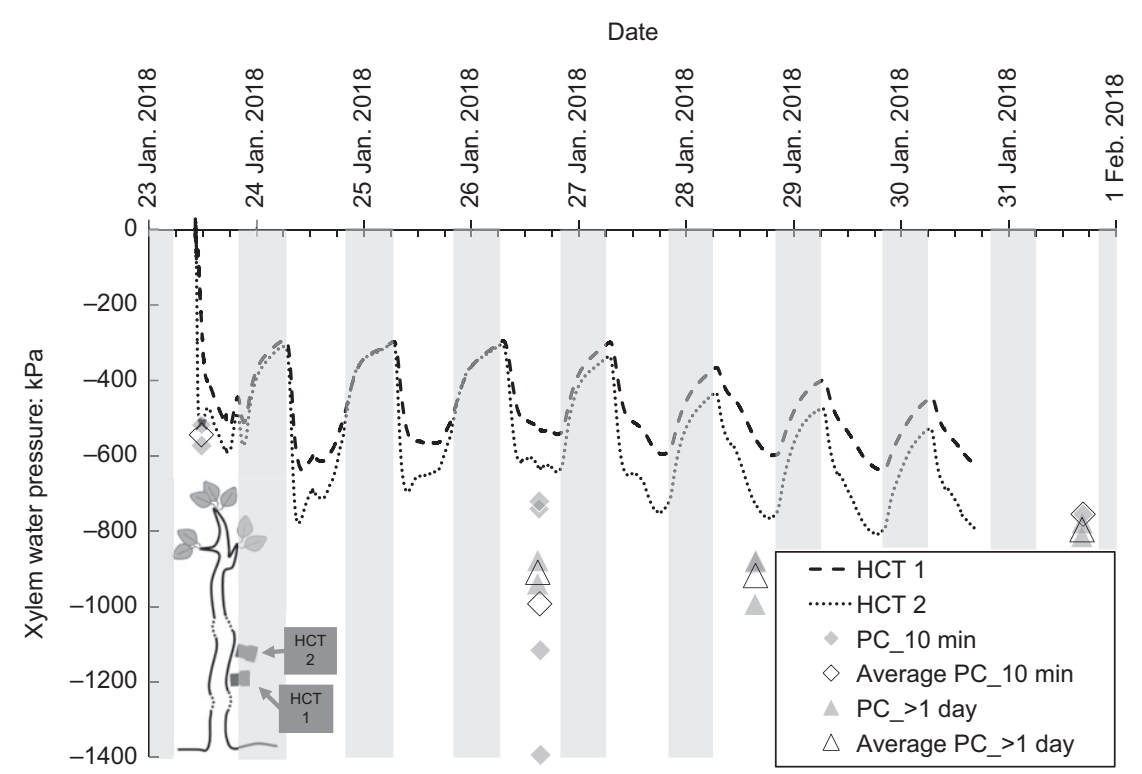

Fig. 11. HCT and pressure chamber measurements on pear tree (shadowed areas represent the 'night time' when the growth lamp is switched off). Pressure chamber measurements are reported individually and average pressure chamber measurement is indicated by empty symbols 


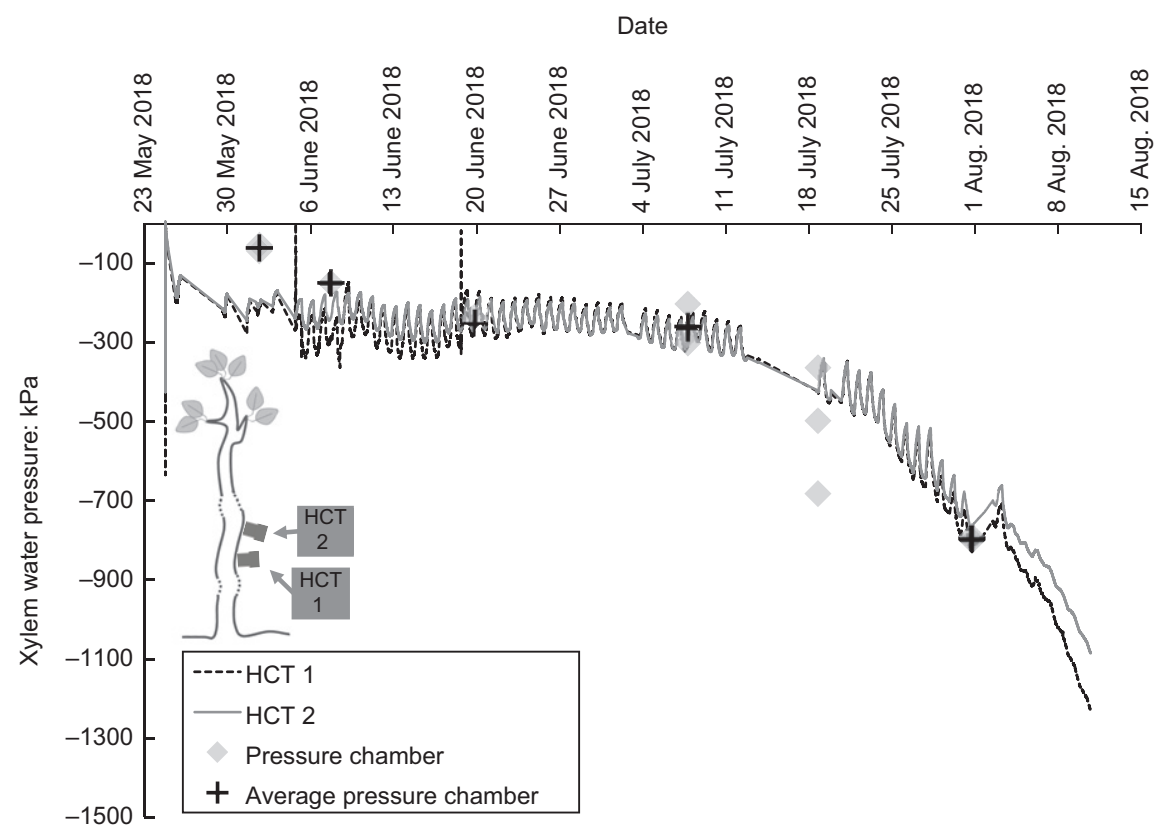

Fig. 12. HCT and pressure chamber measurements on willow tree. Pressure chamber measurements are reported individually and average pressure chamber measurement is indicated by a cross

conductivity that may exist between different branches. In any case, the leaf water pressure measured by the pressure chamber was significantly lower than the water pressure measured on the stem by the HCTs.

The xylem pressure measured by the two HCTs and the pressure chamber showed significant hydraulic gradients during daytime. This is likely to be due to a low xylem hydraulic conductance of the pear tree, which resulted in high hydraulic gradients that need to be established along the stem to accommodate the daily transpiration rate. As a result, the HCT measurements could not be validated by comparison with pressure chamber measurements.

Laboratory test on willow tree. Figure 12 shows the water pressure recorded by HCTs installed on the stem and by the pressure chamber on the leaves. The measurement lasted over two and a half months and a high transpiration rate caused by the fan allowed the generation of a relatively high xylem water pressure in the tree.

The HCT readings show daily cycles similar to the ones observed in the pear tree. The two HCTs fluctuate in phase and read almost the same value of negative water pressure, with discrepancies generally lower than $10 \mathrm{kPa}$. In the period from 4 June 2018 to 18 June 2018, the differences in HCT readings are higher, reaching $40 \mathrm{kPa}$ during daytime. The lower tensiometer (HCT 1) records a lower xylem water pressure than the upper tensiometer (HCT 2). This would indicate a downward flux, which does not make physical sense. A possible explanation is the change of computer connected by way of a USB port to the data acquisition/ direct current (DC) power supply unit. The change of computer might have changed the power supply to the unit and, hence, to the individual tensiometers, causing a slight change in offset of the instrument.

The variation of the HCT readings over a period of a week is shown in Fig. 13. The pattern is similar to the one observed in the pear tree. The xylem water pressure decreased during the daytime and increased again as night-time was approaching. The HCT readings are very close, suggesting a relatively high hydraulic conductance of the xylem. One would therefore expect small gradients in xylem water pressure through the plant, from the stem up to the branches and leaves. Measurements of xylem water pressure at the base of the leaf petiole using the pressure chamber are indeed close to the measurements of xylem water pressure on the stem using the HCTs. As a result, the HCT and pressure chamber measurements could be compared.

The xylem water pressure measured by the HCT is plotted against the xylem water pressure measured by the pressure chamber in Fig. 14. The data points are aligned along the 1:1 line with the only exception being the data point at the lowest value of suction, where the pressure chamber measurement tends to overestimate the value recorded by the HCTs. The reason is not clear and may be associated with the reaction of the plant to the extremely wet conditions (stomata tend to close under very wet conditions (Bradford \& Hsiao, 1982; Else et al., 1996)) and/or to local variability of xylem water pressure. Excluding the first value, the discrepancy between the measurement of xylem water pressure by way of the pressure chamber and the HCT is characterised by a standard deviation lower than $0.05 \mathrm{MPa}$.

\section{Soil-plant continuum test}

The relation between soil and plant was explored in the experiment on the willow tree. HCTs were positioned on the soil in the column at different depths and transpiration was monitored by a balance.

The water pressure in the soil and the tree is shown in Fig. 15(a). The solid symbols on the curves mark the water pressure at 6 a.m., when the water pressure in the xylem reaches its daily maximum, at least in the period 0-40 days. The pressure at $6 \mathrm{a} . \mathrm{m}$. can be considered a pre-dawn value as the growth lamp used to mimic solar light was off overnight. The difference between the (average) water pressure in the xylem and the water pressure measured by the three HCTs in the soil, all recorded at 6 a.m., is plotted in Fig. 15(b). Fig. 15(c) shows the transpiration rate over time derived from the water loss measured by the balance.

Three stages can be identified. In the first stage (days 0 to 38, from 7 June 2018 to 15 July 2018), the pressure differential between the xylem and the soil remains essentially constant. This is associated with a transpiration rate, 


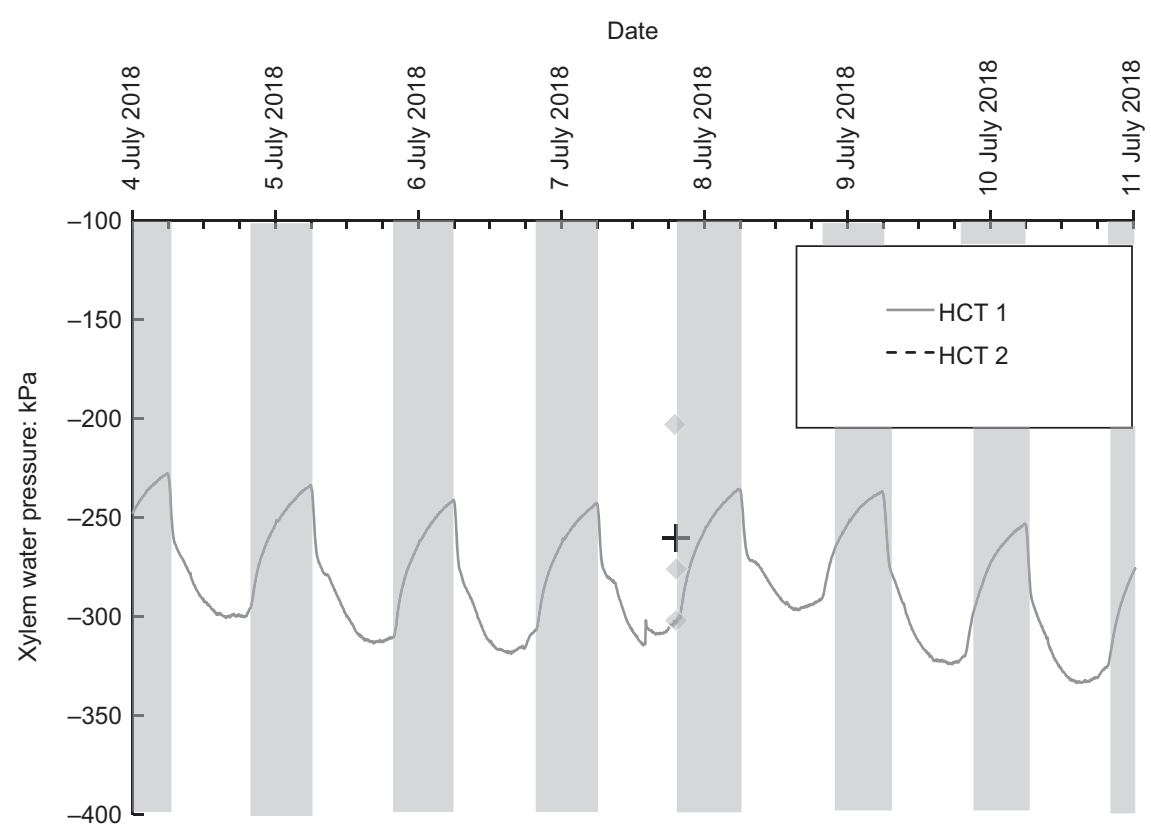

Fig. 13. Zoom of HCT and pressure chamber measurements on willow tree (shadowed areas represent the 'night time' when the growth lamp is switched off)

which also remains fairly constant at its maximum value. At the same time, xylem water pressure shows daily fluctuations, associated with the growth lamp that is switched on during the day and switched off at night. In this stage, the leaves are actively transpiring, and the maximum (potential) transpiration is accommodated by the same pressure differential over the 38 days, indicating that the hydraulic conductivity of the soil remains relatively high. The constant pressure differential between soil and xylem is associated with the energy-limited (potential) transpiration regime.

In the second stage (days 38 to 62, from 15 July 2018 to 8 August 2018), the water pressure differential between soil and xylem significantly increases while the transpiration rate starts to decay. This is associated with the more rapid decrease in soil pore-water pressure in turn associated with the soil degree of saturation approaching its residual state. As the degree of saturation decreases, the soil hydraulic conductivity reduces and the plant increases the pressure differential in the attempt to sustain (unsuccessfully) the maximum transpiration rate. At this stage, daily fluctuations in xylem water pressure are noticeable, indicating that transpiration is still active. The increase in the pressure differential between soil and xylem corresponds to the transition from the energy-limited to the water-limited regime.

In the last stage (days 62 to 70 , from 8 August 2018 to 16 August 2018), the daily fluctuations disappear, while the pressure differential keeps increasing and the transpiration rate decreases to very low values, almost reaching a plateau of residual transpiration. A detail of this last stage is shown in Fig. 16. Between 3 August 2018 and 8 August 2018, daily cycles in the xylem water pressure are still visible, although the xylem pressure increases only slightly overnight. After 8 August 2018 (vertical dotted line), daily fluctuations are not detectable, indicating a condition of wilting of the leaf.

\section{THE USE OF HCT TO INFORM THE}

\section{TRANSPIRATION REDUCTION FUNCTION}

The measurement of the xylem water pressure by way of the HCTs in conjunction with the measurement of porewater pressure in the soil can be potentially used to model the

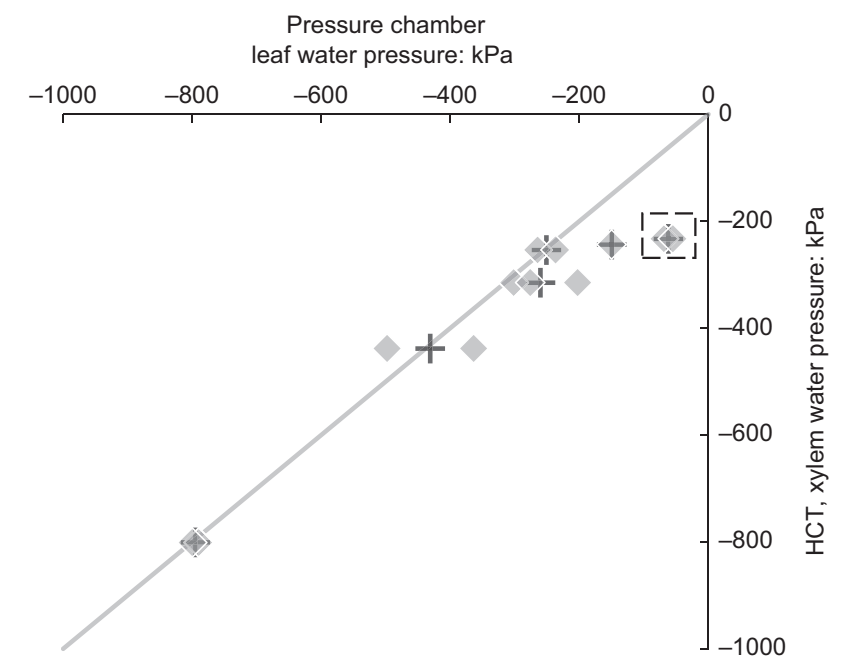

Fig. 14. Comparison of pressure chamber and HCT measurements on willow tree in the laboratory. Pressure chamber measurements are reported against the average measurement of HCT and average pressure chamber measurement is indicated by a cross

Feddes reduction function and, in particular, the parameters $u_{\mathrm{w} 3}$ and $u_{\mathrm{w} 4}$ (Fig. 1). In turn, this can be used to represent transpiration as hydraulic boundary conditions in geotechnical models where interaction with the atmosphere is taken into account.

The results presented in Figs 15 and 16 suggest an approach to derive the two critical parameters of the Feddes reduction function - namely, the parameters $u_{\mathrm{w} 3}$ and $u_{\mathrm{w} 4}$, by way of the joint measurement of water pressure in the xylem and the soil.

The differences between soil pore-water pressures measured by the three HCTs installed on the soil sample and xylem water pressure starts diverging on 15 July 2018 (the first dotted line in Fig. 15(b)), exactly at the time when the transpiration from the soil-plant system starts reducing (Fig. 15(c)). The average soil pore-water pressure when the pressure differential between soil and xylem starts diverging 


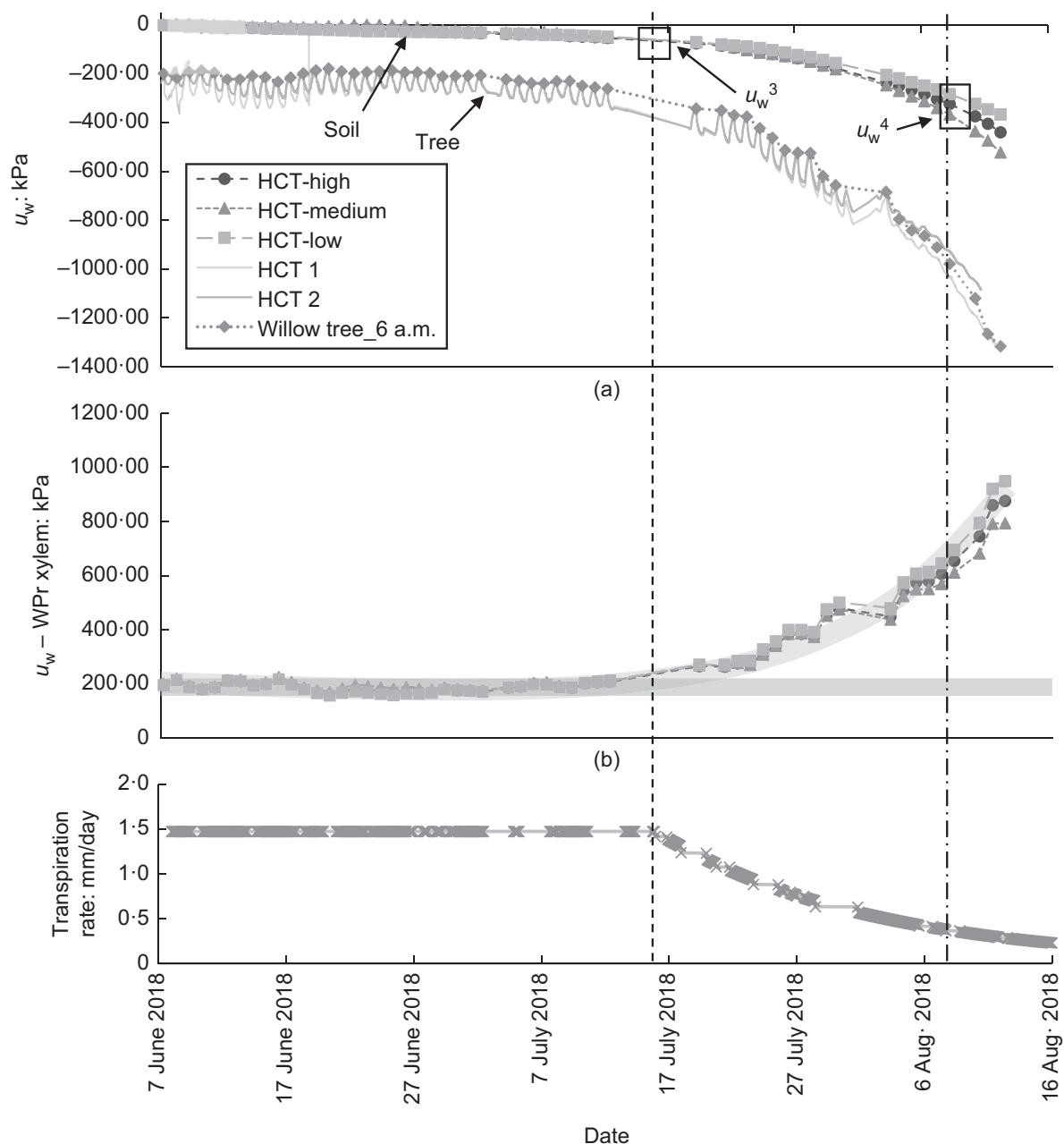

(c)

Fig. 15. (a) Water pressure in soil and tree xylem under induced drought conditions. (b) Difference between the water pressure in the soil at three different depths and the average water pressure measured by two HCTs in the xylem (denoted WPrxylem in the figure). (c) Transpiration rate

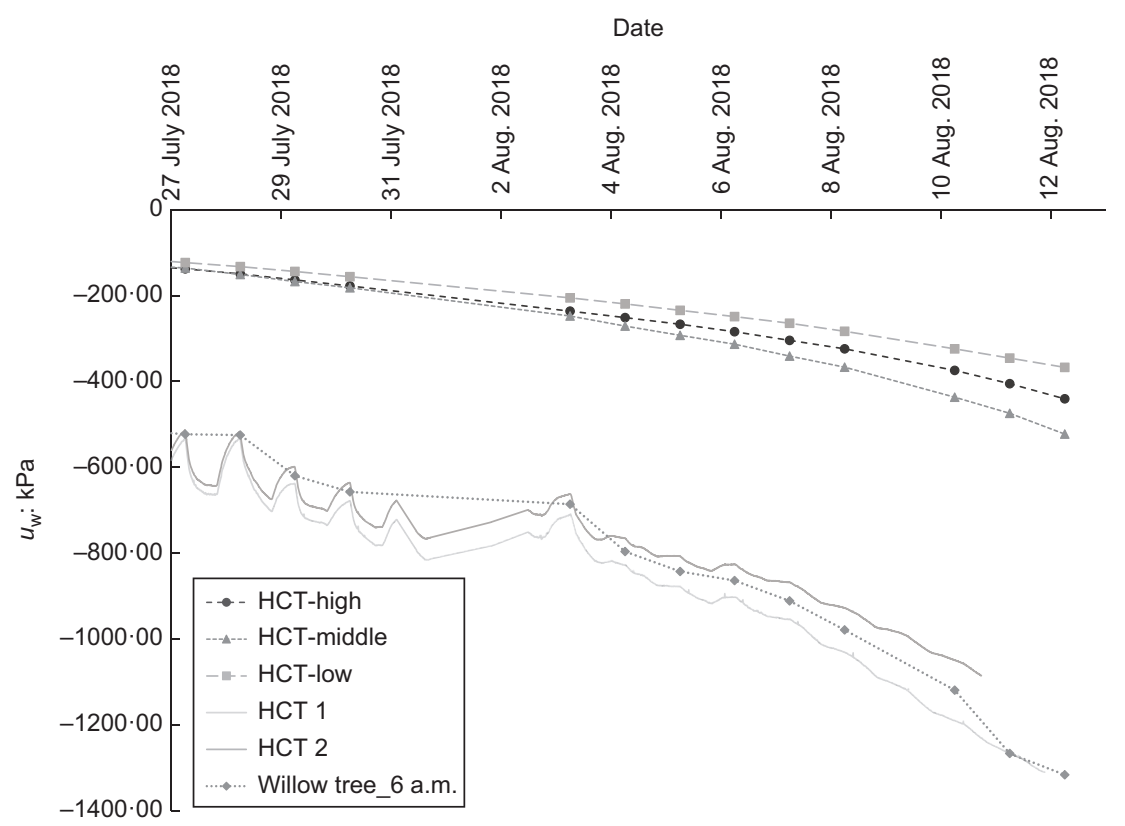

Fig. 16. Evolution of water pressure in soil and xylem under plant stress conditions (from 27 July 2018 to 13 August 2018 )

is associated with the transition from the energy-limited to the water-limited regime and therefore matches the parameter $u_{\mathrm{w} 3}$. The pore-water pressure at the entrance of the water-limited regime on 15 July 2018 was not available and was derived by linear interpolation of the measurements available on 12 July 2018 and 19 July $2018\left(u_{\mathrm{w} 3}=-60 \mathrm{kPa}\right.$, 
as shown in Table 4). The water pressure of the soil was taken as an average of the values measured by the three HCTs installed on the soil sample considering that root biomass was present along the entire sample depth, as detected by post-mortem visual inspection.

The average soil pore-water pressure at the start of the period from 8 August 2018 to 16 August 2018, when xylem water pressure daily fluctuations disappear and transpiration rate reduces by $\sim 75 \%$ (second dotted line in Fig. 15), can be tentatively assumed to represent $u_{\mathrm{w} 4}\left(u_{\mathrm{w} 4}=-312 \mathrm{kPa}\right.$, as shown in Table 4). In order to evaluate the reliability of such an assumption, the reduction function derived experimentally, based on the measured values of transpiration rate and average soil pore-water pressure, was compared with the Feddes function based on the average values of $u_{\mathrm{w} 3}$ and $u_{\mathrm{w} 4}$ inferred from HCT measurements. As shown in Fig. 17, the linear branch of the reduction function in the range between $u_{\mathrm{w} 3}$ and $u_{\mathrm{w} 4}$ (squares) reasonably approximates the nonlinear reduction function derived experimentally (crosses).

Figure 17 also shows the Feddes function based on the parameters commonly adopted in geotechnical applications (diamonds) $\left(u_{\mathrm{w} 3}=-100 \mathrm{kPa}, u_{\mathrm{w} 4}=-1500 \mathrm{kPa}\right.$ (Nyambayo \& Potts, 2010; Briggs et al., 2016)). The discrepancy with the experimental data is remarkable. The use of parameters taken from the literature would predict a higher transpiration rate and, hence, a higher soil suction. This would lead to a non-conservative estimation of shear strength and, hence, slope factor of safety.

Figure 17 therefore highlights the importance of the experimental determination of the Feddes parameters by way of the simultaneous measurement of soil and xylem water pressure using HCTs. The parameter $u_{\mathrm{w} 3}$ marks the transition from the energy-limited to the water-limited regime. This transition occurs when the water pressure in

Table 4. Feddes function parameters used in geotechnical applications and estimated using the HCT measurements in plant and soil

\begin{tabular}{c|c|l|c}
\hline & $\begin{array}{c}\text { Typically } \\
\text { adopted } \\
\text { in geotechnical } \\
\text { applications: } \\
\mathrm{kPa}\end{array}$ & $\begin{array}{l}\text { Experimentally derived from HCT } \\
\text { measurement }\end{array}$ \\
\cline { 3 - 4 } & -100 & $\begin{array}{l}\text { 12 July 2018 } \\
\text { 19 July 2018 } \\
\text { 15 July 2018 (by linear } \\
\text { interpolation) }\end{array}$ & $\begin{array}{c}\text { Average of } \\
\text { three HCTs } \\
\text { in the soil: kPa }\end{array}$ \\
\hline$u_{\mathrm{w} 3}$ & 8 August 2018 & -61 \\
$u_{\mathrm{w} 4}$ & -1500 & & -60 \\
\hline
\end{tabular}

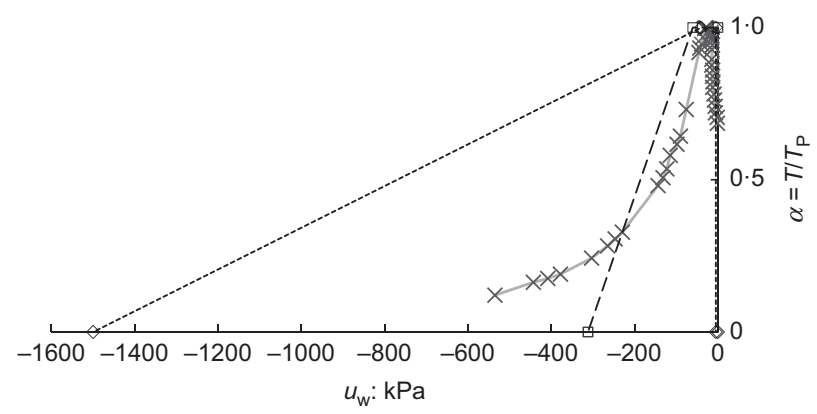

Fig. 17. Transpiration reduction function derived from experimental data (crosses), estimated using the parameters proposed by Feddes et al. (1978) (diamonds), and estimated using the parameters derived from HCT measurements in plant and soil (squares) the xylem reaches a threshold that causes the size of the stomata to start reducing, which in turn causes the transpiration rate to abate. This threshold is plant species dependent, but the water pressure in the soil when this condition is attained also depends on the hydraulic characteristics of the soil. As a result, the parameter $u_{\mathrm{w} 3}$ is likely to be dependent on the coupling between a specific soil and a specific plant and therefore requires a joint measurement of water pressure in the soil and the plant to be determined. The same considerations apply to the parameter $u_{\mathrm{w} 4}$ associated with a threshold pressure in the xylem, which causes the leaf to wilt (Fig. 17).

\section{CONCLUSIONS}

The paper has demonstrated for the first time the use of the HCT for measuring xylem water pressure in plants. HCTs were installed on the branch of a chestnut in the field and on the trunks of a pear tree and a willow tree in the laboratory. The HCT measurement was compared to the measurement of xylem water pressure at the base of leaf petioles using a pressure chamber for validation.

The HCTs were placed at closer distance $(\sim 10 \mathrm{~cm})$ on the branch or stem and their measurement always appeared to be very consistent. Both under field and laboratory conditions, the trend of xylem water pressure recorded by the HCTs was coherent with the boundary conditions and the natural reaction of the plant (i.e. stomata closure and higher xylem water pressure at night-time).

The non-negligible gradients along the pear tree made the comparison between the pressure chamber and the HCTs unreliable. These gradients were assumed to be due to the low hydraulic conductance of the xylem.

On the other hand, measurement of xylem water pressure by HCTs on the chestnut in the field and on the willow tree in the laboratory could be compared to the readings obtained by the pressure chamber. Data points representing the HCT measurement against the pressure chamber measurement fairly aligned on the 1:1 line. This was taken as a validation of the HCT against the well-established pressure chamber technique. The HCT therefore seems to be a viable and convenient instrument for xylem water pressure measurement, although further validation involving different species and environmental conditions should be pursued. In addition, it would be beneficial to compare the HCT to other techniques (i.e. thermocouple psychrometer).

A straightforward geotechnical application of the xylem water pressure measurement is the derivation of the parameters characterising the reduction function used to model transpiration as an hydraulic boundary condition. The interpretation of the simultaneous measurement of water pressure in the soil and xylem allowed for an experimental determination of the Feddes reduction function parameters, at least for the laboratory test presented in the paper. Further studies are required to validate the HCT-based method suggested in the paper. However, this preliminary study has highlighted the relevance of the experimental determination of the reduction function parameters compared to the approach based on borrowing values from the agricultural literature, which can lead to misleading prediction of the transpiration rate and a non-conservative prediction of soil shear strength and, hence, the slope factor of safety.

The use of HCT on plants is a step change in the understanding and modelling of the effect of plant transpiration on suction and the moisture regime in vegetated ground. HCTs have been used for more than 20 years in geotechnical engineering and this instrument is available in many research laboratories. Installing HCTs on stems and branches is quite straightforward and this will allow the analysis of the soil and 
the plant as a continuum in a single experimental set-up, rather than borrowing transpiration models developed by plant scientists for their specific applications.

\section{ACKNOWLEDGEMENT}

The authors wish to acknowledge the support of the European Commission by way of the Marie SkłodowskaCurie Innovative Training Networks (ITN-ETN) project TERRE 'Training engineers and researchers to rethink geotechnical engineering for a low carbon future' (H2020MSCA-ITN-2015-675762).

\author{
NOTATION \\ $h_{1}, h_{2}$ relative heights \\ $K\left(u_{\mathrm{w}}\right) \quad$ hydraulic conductivity \\ $S_{\mathrm{r}}$ degree of saturation \\ $T$ actual transpiration \\ $T_{\mathrm{P}}$ potential (energy-limited) transpiration \\ $u_{\mathrm{w}}$ pore-water pressure \\ $\alpha$ reduction factor
}

\section{REFERENCES}

Balling, A. \& Zimmermann, U. (1990). Comparative measurements of xylem pressure of Nicotiana plants by means of the pressure bomb ad pressure probe. Planta 182, No. 3, 325-338.

Begg, J. \& Turner, N. (1970). Water potential gradients in field tobacco. Plant Physiol. 46, No. 2, 343-346.

Boyer, J. S. (1967). Leaf water potentials measured with a pressure chamber. Plant Physiol. 42, No. 1, 133-137.

Boyer, J. S. (1995). Measuring the water status of plants and soils. San Diego, CA, USA: Academic Press.

Bradford, K. J. \& Hsiao, T. C. (1982). Stomatal behavior and water relations of waterlogged tomato plants. Plant Physiol. 70, No. 5, 1508-1513.

Briggs, K. M., Smethurst, J. A., Powrie, W. \& O'Brien, A. S. (2016). The influence of tree root water uptake on the long term hydrology of a clay fill railway embankment. Transp. Geotech. $\mathbf{9}$, $31-48$.

Brooks, R. \& Corey, T. (1964). Hydraulic properties of porous media, Hydrology Papers 3. Fort Collins, CO, USA: Colorado State University.

Brown, P. \& Tanner, C. (1981). Alfalfa water potential measurement: a comparison of pressure chamber and leaf dew-point hygrometers. Crop Sci. 21, No. 2, 240-244.

Bulut, R. \& Leong, E. (2008). Indirect measurement of suction. In Laboratory and field testing of unsaturated soils (eds A. Tarantino, E. Romero and Y. J. Cui), pp. 21-32. Dordrecht, the Netherlands: Springer.

Campbell, G. \& Gardner, W. (1971). Psychrometric measurement of soil water potential: temperature and bulk density effect. Soil Sci. Soc. Am. J. 35, No. 1, 8-12.

Canny, M. J. (1977). Flow and transport in plants. Ann. Rev. Fluid Mech. 9, 275-296.

Deloire, A. \& Heyns, D. (2011). The leaf water potentials: principles, method and thresholds. Wynboer 265, 119-121.

Else, M. A., Tiekstra, A. E., Croker, S. J., Davies, W. J. \& Jackson, M. B. (1996). Stomatal closure in flooded tomato plants involves abscisic acid and a chemically unidentified antitranspirant in xylem sap. Plant Physiol. 112, No. 1, 239-247.

Feddes, R. (1982). Simulation of field water use and crop yield. In Simulation of plant growth and crop production (eds F. W. T. Penning de Vries and H. H. van Laar), pp. 194-209. Wageningen, the Netherlands: Pudoc.

Feddes, R. A., Kowalik, P. J. \& Zaradny, H. (1978). Simulation of field water use and crop yield, Simulation Monograph. Wageningen, the Netherlands: Pudoc.

Garg, A., Leung, A. K. \& Ng, C. W. W. (2015). Transpiration reduction and root distribution functions for a non-crop species Schefflera heptaphylla. Catena 135, 78-82.

Gollan, T., Turner, N. \& Schulze, E. D. (1985). The responses of stomata and leaf gas exchange to vapour pressure deficits and soil water content. III. In the sclerophyllous woody species Nerium oleander. Oecologia 65, No. 3, 356-362.

Goode, J. \& Higgs, K. (1973). Water, osmotic and pressure potential relationships in apple leaves. J. Hortic. Sci. 48, No. 2, 203-215.

Greco, R., Comegna, L., Damiano, E., Guida, A., Olivares, L. \& Picarelli, L. (2013). Hydrological modelling of a slope covered with shallow pyroclastic deposits from field monitoring data. Hydrol. Earth Syst. Sci. 17, No. 10, 4001-4013, https://doi.org/ 10.5194/hess-17-4001-2013.

Hemmati, S., Gatmiri, B., Cui, Y. J. \& Vincent, M. (2010). Soilvegetation-atmosphere interaction by a multiphysics approach. J. Multiscale Modelling 2, No. 03n04, 163-184.

Indraratna, B., Fatahi, B. \& Khabbaz, H. (2006). Numerical analysis of matric suction effects of tree roots. Proc. Instn Civ. Engrs Geotech. Engng 159, No. 2, 77-90, https://doi.org/10.1680/geng. 2006.159.2.77.

Jones, H. (2006). Monitoring plant and soil water status: established and novel methods revisited and their relevance to studies of drought tolerance. J. Exp. Bot. 58, No. 2, 119-130.

Kocher, P., Gebauer, T., Horna, V. \& Leuschner, C. (2009). Leaf water status and stem xylem flux in relation to soil drought in five temperate broad-leaved tree species with contrasting water use strategies. Ann. For. Sci. 66, No. 1, article 101, https://doi.org/10.1051/forest/2008076.

Lang, A. \& Barrs, H. (1965). An apparatus for measuring water potential in the xylem of intact plants. Aust. J. Biol. Sci. 18, No. 3, 487-497.

Marinho, F. A. M., Take, W. A. \& Tarantino, A. (2008). Measurement of matric suction using tensiometric and axis translation techniques. In Laboratory and field testing of unsaturated soils (eds A. Tarantino, E. Romero and Y. J. Cui), pp. 3-19. Dordrecht, the Netherlands: Springer.

Martinez, E., Cancela, J., Cuesta, T. \& Neira, X. (2011). Review. Use of psychrometers in field measurements of plant material: accuracy and handling difficulties. Span. J. Agric. Res. 9, No. 1, 313-328.

Meron, M., Grimes, D., Phene, C. \& Davis, K. (1987). Pressure chamber procedures for leaf water potential measurements in cotton. Irrig. Sci. 8, No. 3, 215-222.

Nyambayo, V. \& Potts, D. (2010). Numerical simulation of evapotranspiration using a root water uptake model. Comput. Geotech. 37, No. 1-2, 175-186.

Pagano, L., Reder, A. \& Rianna, G. (2019). Effects of vegetation on hydrological response of silty volcanic covers. Can. Geotech. J. 56, No. 9, 1261-1277, https://doi.org/10.1139/cgj-2017-0625.

Patakas, A., Noitsakis, B. \& Chouzouri, A. (2005). Optimization of irrigation water use in grapewines using the relationship between transpiration and plant water status. Agric. Ecosyst. Environ. 106, No. 2-3, 253-259.

Pickard, W. (1981). The ascent of sap in plants. Prog. Biophys. Mol. Biol. 37, 181-229.

PMS Instrument Company (2019). https://www.pmsinstrument. $\mathrm{com} /($ accessed 15/05/2019).

Richter, H. (1973). Frictional potential losses and total water potential in plants: a re-evaluation. J. Exp. Bot. 24, No. 83, 983-994.

Rodrigues Afonso Dias, A. (2019). The effect of vegetation on slope stability of shallow pyrooclastic soil covers. $\mathrm{PhD}$ thesis, Université de Montpellier, Montpellier, France.

Scholander, P., Hammel, H. \& Breadstreet, E. H. E. (1965). Sap pressure in vascular plants: negative hydrostatic pressure can be measured in plants. Science 148, No. 3668, 339-346.

Tarantino, A. (2002). Panel lecture: direct measurement of soil water tension. In Unsaturated soils: proceedings of the third international conference, UNSAT2002 (eds J. F. T. Jucá, T. M. P. de Campos and F. A. M. Marinho), vol. 3, pp. 1005-1017. Lisse, the Netherlands: A. A. Balkema (Taylor \& Francis).

Tarantino, A. \& Mongiovì, L. (2001). Experimental procedures and cavitation mechanisms in tensiometer measurements. In Unsaturated soil concepts and their application in geotechnical practice (ed. T. G. Toll), pp. 189-210. Dordrecht, the Netherlands: Springer.

Tarantino, A. \& Mongiovì, L. (2002). Design and construction of a tensiometer for direct measurement of matric suction, 
In Unsaturated soils: proceedings of the third international conference, UNSAT2002 (eds J. F. T. Jucá, T. M. P. de Campos and F. A. M. Marinho), vol. 1, pp. 319-324. Lisse, the Netherlands: A. A. Balkema (Taylor \& Francis).

Tarantino, A. \& Mongiovì, L. (2003). Calibration of tensiometer for direct measurement of matric suction. Géotechnique 53, No. 1, 137-141, https://doi.org/10.1680/geot.2003.53.1.137.

Tsiampousi, A., Zdravkovic, L. \& Potts, D. M. (2017). Numerical study of the effect of soil-atmosphere interaction on the stability and serviceability of cut slopes in London clay. Can. Geotech. J. 54, No. 3, 405-418, https://doi.org/10.1139/ cgj-2016-0319.

Turner, N., Spurway, R. \& Schulze, E. D. (1984). Comparison of water potentials measured by in situ psychrometry and pressure chamber in morphologically different species. Plant Physiol. 74, No. 2, 316-319.
Utset, A., Ruiz, M. E., Garcia, J. \& Feddes, R. A. (2000). A SWACROP-based potato root water uptake function as determined under tropical conditions. Potato Res. 43, No. 1, 19-29.

Wei, C., Steudle, E., Tyree, M. \& Lintilhac, P. (2001). The essentials of direct xylem pressure measurement. Plant, Cell Environ. 24, No. $5,459-555$.

Wesseling, J. G. (1991). Meerjarige simulatie van grondwaterstroming voor verschillende bodemprofielen, grondwatertrappen en gewassen met het model SWATRE, Rapport/DLO-Staring Centrum no. 152. Wageningen, the Netherlands: DLO-Staring Centre (in Dutch).

Zhu, H. \& Zhang, L. (2019). Root-soil-water hydrological interaction and its impact on slope stability. Georisk: Assessment and Management of Risk for Engineered Systems and Geohazards 13, No. 4, 349-359, https://doi.org/10.1080/17499518.2019. 1616098. 